\section{Isolation of Chlamydia from the Urethra of a Woman}

\author{
E. M. C. DUNLOP, S. DAROUGAR, M. J. HARE, \\ J. D. TREHARNE, R. ST. C. DWYER
}

British Medical fournal, 1972, 1, 386

Isolates of Chlamydia were obtained from the urethra and cervix of a woman. She was examined because her husband was suffering from an ocular infection due to a Chlamydianamely, TRIC agent-and had low-grade urethritis.

\section{Case History}

A woman aged 26 presented in May 1970 because her husband had been found to be suffering from keratoconjunctivitis due to TRIC agent. His ocular symptoms had started in early December 1969 about the time of his last admitted extramarital intercourse. She had had about five attacks of "burning" discomfort on micturition in the previous two years accompanied by increased frequency of micturition by day but not by night. The last attack had started five days before her attendance. Colposcopy showed a congested but otherwise normal cervical erosion and an inflamed urethral meatus. Strands of mucopus were present on an otherwise normal rectal mucosa. There were 30 polymorphonuclear leucocytes per high-power field in a smear of the cervical mucus stained by Gram's method, 5 per high-power field in the urethral smear, and 30 per high-power field in the rectal smear; organsims resembling gonococci were not seen. Biopsy of the cervix showed infiltration with lymphocytes and plasma cells. Ocular and general examination showed no abnormality.

Materials for culture for Chlamydia were collected from the urethral meatus with a swab, from within the urethra with a curette (Dunlop et al., 1965), and from the cervix and rectum by means of swabs and scrapers. Each specimen was cultured in irradiated McCoy cells by use of a simplified method (Darougar et al., 1971). Isolates of Chlamydia were obtained from the urethral scrapings and from the cervical swab and scrapings but not from materials from the urethral meatus or the rectum or from the first part of the voided urine. In cell culture these isolates produced inclusions that stained with iodine, hence they were subgroup $A$ Chlamydia (Gordon and Quan, 1965).

Only the isolate from the urethra was available for typing by a microimmunofluorescence test (Treharne et al., 1971). It was type E TRIC agent. Microimmunofluorescence tests of the patient's serum showed the highest levels of antichlamydial antibody to be against type E TRIC agent (titre 1 in 32) and against lymphogranuloma venereum (L.G.V.) agent type II (titre 1 in 64); with serum from her husband the highest titre (1 in 128) was against B and E TRIC agent and against L.G.V. II and III. A complementfixation test of the patient's serum for group anti-chlamydial antibody (L.G.V. C.F.T.) repeatedly gave negative results; with serum from her husband it gave partial fixation only.

Cultures for gonococci, serological tests for syphilis, and examination of smears and cultures of the vaginal secretions for

Whitechapel Clinic, The London Hospital, London E1 1BB

E. M. C. DUNLOP, M.D., P.R.C.P., Consultant Venereologist

M. J. HARE, M.B., B.S., D.OBST.R.c.o.G., Research Registrar

Virus Laboratory, Department of Clinical Ophthalmology, Institute of Ophthalmology, London W.C.1

S. DAROUGAR, M.D, D.T.M.\&H., Senior Lecturer

J. D. TREHARNE, B.SC., Lecturer

R. ST. C. DWYER, B.SC., Research Assistant
Trichomonas vaginalis and candida gave negative results. The centrifuged deposit of a midstream specimen of urine contained 3 leucocytes per 1/6 field; Escherichia coli, insensitive to tetracycline, was cultured at a concentration of $10^{5}$ organisms per $\mathrm{ml}$ of urine. Profuse growths of $E$. coli were obtained from the vagina and from the urethral meatus.

Oxytetracycline $250 \mathrm{mg}$ four times a day for 21 days was given for the chlamydial infection; the urinary symptoms subsided promptly and did not return. Follow-up examinations, including tests for Chlamydia, gave negative results. On two occasions a midstream specimen of urine was examined-on both occasions the deposit was normal and $E$. coli was cultured at a concentration of $<4.6 \times 10^{4}$ organisms per $\mathrm{ml}$ of urine.

\section{Comment}

It is possible that the presence of $E$. coli in the urine was due to contamination. The isolation of Chlamydia from scrapings from within the urethra suggests that the urethra was infected by that agent and not simply contaminated with material from the cervix. The isolate was type E TRIC agent and both husband and wife had antibodies in their sera to this type. In our experience when an adult presents with fresh ocular infection by TRIC agent that agent can usually be recovered from the genital tract. Although in this case the husband had low-grade urethritis tests of urethral material for Chlamydia gave negative results; however, some six months had elapsed from the onset of his ocular symptoms to the time of genital tests.

It has been implied that Chlamydia may be a cause of the urethral syndrome (British Medical fournal, 1968). Halberstaedter and Prowazek (1909) reported the presence of the inclusions, now known by their names, in material from the urethral meatus of the mother of a newborn baby suffering from non-gonococcal ophthalmia neonatorum. Subsequently it was generally believed that the inclusions in that case were contaminants from the cervix infected by Chlamydia.

Culture in irradiated $\mathrm{McCoy}$ cells provided a more sensitive method for isolation of Chlamydia than culture in yolk sac for materials from the conjunctiva, the urethra of the male, and the cervix of the female (Gordon et al., 1969). By use of this method the agent has also been isolated from the rectum (Dunlop et al., 1971) and now from the urethra of a woman.

We are grateful to Dr. A. E. Wilkinson, V.D. Reference Laboratory, The London Hospital, for carrying out cultures for bacteria, $T$. vaginalis and candida, and serological tests for syphilis; to the late Professor C. F. Barwell, The London Hospital, for carrying out the L.G.V. C.F.T.; and to Professor Norman Ashton, the Institute of Ophthalmology, for the histological studies.

\section{References}

British Medical Foumal, 1968, 2, 192

Darougar, S., Kinnison, J. R., and Jones, B. R. (1971). In International Congress Series, No. 223, ed. Roger L. Nichols, p. 63. Amsterdam. Excerpta Medica.

Dunlop, E. M. C., et al. (1965). Lancet, 1, 1125, 1286

Dunlop, E. M. C., Hare, M. J., Darougar, S., and Jones, B. R. (1971). In International Conoress Series, No. 223, ed. Roger L. Nichols, p. 507. Amsterdam, Excerpta Medica.

Gordon, F. B., et al. (1969). Ұournal of Infectious Diseases, 120, 451. Gordon, F. B., and Quan, A. L. (1965). Fournal of Infectious Diseases,

115. 186. Wochenschrift, 46, 1839.

Treharne, J. D. Katzenelson, E. Davey, S., and Gray, S. (1971). In International Congress Series, No. 223, ed. Roger L. Nichols, p. 289. Amsterdam, Excerpta Medica. 